\title{
Hiệu quả của chính sách bình thường mới trong việc "hồi sinh" các doanh nghiệp
}

\author{
Phạm Hà Trang, Đỗ Thị Hương Trà, Lê Thu Trang, \\ Cao Thùy Trang, Nguyễn Thị Phương Thảo \\ Đại học Quốc gia Hà Nội \\ Preprint DOI: 10.31219/osf.io/8z5x9 \\ Ngày 10 Tháng Hai 2022
}

Vào tháng 12/2019, mầm mống virus SARS-CoV-2 cho một đại dịch toàn cầu mang tên COVID-19 bắt đầu được phát tán, không ai có thể ngờ rằng được sự kiện này sẽ là xuất phát điểm cho một bước ngoặt lịch sử của toàn nhân loại. Cho đến nay, đại dịch COVID-19 vẫn đang diễn biến vô cùng phức tạp tại nhiều quốc gia trên thế giới (La, 2020; Vuong, Q.H., 2022), gây hoang mang cho con người bởi sự nâng cấp của những biến chủng virus mới với khả năng lây nhiễm cao hơn, nhanh hơn và "thông minh" hơn. Với khả năng càn quét trên phạm vi toàn cầu một cách khốc liệt, COVID-19 để lại sức ảnh hưởng tiêu cực to lớn chưa từng có tiền lệ lên nhiều khía cạnh khác nhau của xã hội như kinh tế, giáo dục, lao động, người dân, đời sống sinh hoạt,... và không thể không kể đến là các doanh nghiệp.

Doanh nghiệp là yếu tố chiếm vị trí quan trọng trong nền kinh tế, quyết định đến sự chuyển dịch các cơ cấu lớn của nền kinh tế mỗi quốc gia. Quá trình phát triển của doanh nghiệp luôn song hành với quá trình theo đuổi mục tiêu công nghiệp hóa, hiện đại hóa đất nước, xây dựng một nền kinh tế vững vàng ổn định để phát huy năng lực phát triển trong thời kì hội nhập. Không chỉ dừng lại ở đó, những bước thăng trầm của doanh nghiệp cũng có tác động không nhỏ tới xã hội, bởi lẽ nó quyết định đến sự ổn định các mặt thực tiễn trong xã hội qua các hoạt động của mình. Như vậy, khi doanh nghiệp bị tác động tiêu cực cũng đồng nghĩa với việc nền kinh tế, xã hội con người bị ảnh hưởng nghiêm trọng. Và đó chính là thực tiễn mà các nước trên thế giới nói chung và Việt Nam nói riêng đang phải đối mặt, cú va chạm đối với đại 
dịch toàn cầu làm cho đà phát triển của các doanh nghiệp bị buộc kìm hãm. Theo Trưởng ban Pháp chế VCCI - ông Đậu Anh Tuấn, đại dịch Covid-19 tác động rất tiêu cực đến doanh nghiệp tại Việt Nam. Trong đó, doanh nghiệp cho biết, họ chịu ảnh hưởng ở mức "phần lớn" hoặc "hoàn toàn tiêu cực" chiếm 87,2\%. Doanh nghiệp phản hồi lại rằng rằng họ "không bị ảnh hưởng gi" chỉ chiếm $11 \%$ và gần $2 \%$ ghi nhận tác động "hoàn toàn tích cực" hoặc "phần lớn tích cực".(Vân Thanh, 2021)

Ảnh hưởng của đại dịch gây ra thách thức lớn, là bài toán hoàn toàn mới cho các doanh nghiệp hay nói rộng ra là cho sự tăng trưởng kinh tế của Việt Nam. Đại dịch COVID-19 không chỉ là mối nguy tới sức khỏe cộng đồng mà còn là sự tấn công trực diện tới "sức khỏe" doanh nghiệp. Nhận thức được mức độ nguy hiểm của COVID-19 và chấp hành nghiêm túc các chỉ thị mà Nhà nước đề ra, ban đầu doanh nghiệp ứng phó bằng cách cho người lao động thực hiện nghiêm túc việc đeo khẩu trang và sát khuẩn liên tục nhưng sau đó nhiều doanh nghiệp đã chủ động cho những người lao động thôi việc hay một số doanh nghiệp bị buộc phải đóng băng, tiêu biểu là các doanh nghiệp hàng không hay đứng trước nguy cơ có thể sẽ phải rút khỏi thị trường. Điều này dẫn tới tình trạng thị trường thiếu hụt nguồn cung, quy trình từ sản xuất đến tiêu thụ sản phẩm hoặc cung ứng dịch vụ bị thay đổi trầm trọng mà đa số thay đổi ở đây là theo hướng tiêu cực. Sự thay đổi đó có thể làm cho thu nhập của người lao động giảm sút một cách nặng nề, họ không thể đi làm, một số thì thất nghiệp tạm thời số khác kém may mắn hơn thì bị đào thải do doanh nghiệp không còn đủ khả năng chi trả lương bởi lợi nhuận không còn như trước. Từ đó ta có thể thấy được chất mức sống của người lao động vốn đã không cao nay còn thấp hơn nữa. Ảnh hưởng của COVID-19 mang đến nhiều rủi ro mà không một doanh nghiệp nào có thể lường trước được, muốn tồn tại qua đại dịch họ buộc phải đối mặt, buộc phải thích nghi, tính toán và đưa ra những giải pháp một cách nhanh nhất, linh hoạt trước diễn biến phức tạp của dịch bệnh nhưng vẫn phải hợp lí và thiết thực. Tuy nhiên, điều này không phải dễ cũng không phải doanh nghiệp nào cũng có thể tự mình xoay sở để đưa ra phương án theo đúng tiêu chí.

Cho đến thời điểm hiện tại, tức là khoảng 2 năm kể từ khi dịch bệnh bùng phát nhưng tới giờ vẫn chưa có dấu hiệu chấm dứt, doanh nghiệp không thể mãi đình trệ, bó tay trước đại dịch nếu không sẽ tạo nên một hậu quả khôn lường đối với nền kinh tế. Nhận thấy tính cấp thiết của vấn đề này, Nhà nước đã can thiệp kịp thời cho rằng: chúng ta không hề biết điểm dừng của bệnh dịch nhưng chúng ta cũng không thể cứ mãi ngồi im một chỗ tìm cách xoay sở, ngay khi bệnh dịch còn có thể kiểm soát, việc "sống chung" với dịch là hoàn toàn hợp lí thiết lập trạng thái "bình thường mới" 
hậu COVID-19. Bên cạnh việc các nhà lãnh đạo, đội ngũ quản lí điều hướng rủi ro, xác định thời điểm và phương pháp để đưa lực lượng lao động trở lại sau khi gỡ bỏ lệnh cấm thì Nhà nước Việt Nam cũng đề ra những chính sách, những nghị quyết hỗ trợ tháo gỡ khó khăn, thúc đẩy phát triển chuỗi cung ứng trong sản xuất và kinh doanh, phục hồi các doanh nghiệp bị ảnh hưởng bởi COVID-19. Những chính sách Chính phủ đưa ra cho là đảm bảo khắc phục được tính cấp thiết của vấn đề, hoàn toàn hợp lí và là một đòn bẩy thúc đẩy sự đổi mới về hình thức cũng như đổi mới về tư duy của các doanh nghiệp. Vậy hiệu quả của những chính sách đó mang lại được đánh giá cao tới mức nào và có vai trò gì trong việc "hồi sinh" các doanh nghiệp thời hậu COVID-19?

Trong hai năm trở lại đây, dịch Covid 19 diễn biến phức tạp, khó lường với tốc độ lây lan cao một cách chóng mặt gây ảnh hưởng nghiêm trọng về mọi mặt kinh tế, chính trị, văn hóa, xã hội, giáo dục,....trên toàn Thế giới. Năm 2020 qua đi với nhiều những biến động nghiêm trọng nhất trong lịch sử nhân loại, con người bước vào 2021 với một niềm tin mãnh liệt rằng Covid 19 sẽ được kiểm soát và nền kinh tế sẽ sớm được phục hồi nhanh chóng sau đại dịch. Tuy nhiên, với sự lây lan khủng khiếp với các biến chủng như Alpha, Beta,... giờ là các biến chủng đáng quan ngại như Delta, và đặc biệt một biến thể mới xuất hiện không lâu Omicron. Mặc dù năm 2021 ghi nhận sự phục hồi kinh tế nhanh hơn kỳ vọng song vẫn còn một số thách thức tồn tại đang chờ được giải quyết. (Ngọc, 2021)

Ở Việt Nam, đợt bùng phát dịch lần thứ tư do biến chủng Delta gây ra tác động lớn đến đời sống kinh tế-xã hội,hoạt động sản xuất kinh doanh của các doanh nghiệp và người dân khi lan rộng ra hầu hết các tỉnh và thành phố lớn như Hà Nội, Thành phố Hồ Chí Minh, Bình Dương,...những nơi đi đầu trong phong trào sản xuất và phát triển kinh tế, là nơi tập trung đông dân cư, các khu công nghiệp, nhà máy sản xuất quy mô lớn. Đặc biệt, đợt giãn cách xã hội hồi tháng 7/2021 theo chỉ thị 16 của Thủ tướng Chính phủ kéo dài hơn 2 tháng gây ảnh hưởng nghiêm trọng đến đời sống, hoạt động trao đổi, mua bán, sản xuất của người dân, doanh nghiệp, tựu chung lại là ảnh hưởng lớn đến nền kinh tế và kết quả tăng trưởng GDP cả nước. 
Theo Tổng cục Thống kê, GDP quý III năm 2021 có mức giảm mạnh nhất kể từ khi Việt Nam công bố GDP theo quý. Theo đó, tốc độ tăng trưởng GDP 6 tháng đầu năm 2021 chỉ đạt 5,64\%, dù vượt trội hơn so với năm 2020 là 3.82\% nhưng vẫn thấp hơn cùng kỳ năm 2018 là 1,41\% và năm 2019 là $1,13 \%$ do tác động của dịch Covid gây đình trệ sản xuất, kinh doanh. Dịch Covid 19 diễn ra phức tạp buộc các doanh nghiệp phải ngừng sản xuất, và khi buộc phải ngừng sản xuất sẽ dẫn đến nhiều đối tác, doanh nghiệp nước ngoài phải chấm dứt hợp đồng khiến thu hút vốn đầu tư trực tiếp nước ngoài $\mathrm{FDI}$ đạt thấp, chỉ tăng 3,1\% năm 2021 và $7,4 \%$ trong 6 tháng đầu năm 2021 so với cùng kỳ. Tỷ lệ lao động thất nghiệp và thiếu việc làm tăng cao do phải thực hiện giãn cách xã hội theo chỉ thị 16 của Thủ tướng Chính phủ.(BBT, 2021)

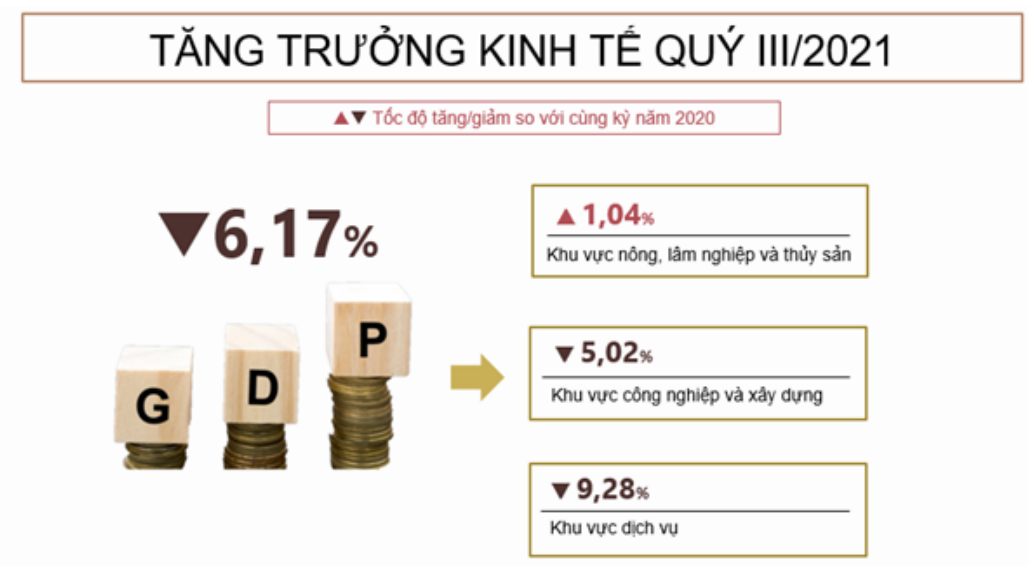

Hình 1. Tăng trưởng các khu vục kinh tế quý III/2021. Nguồn: Tổng cục thống $k \hat{e}$

Theo số liệu số liệu của tổ chức dịch vụ pháp lý Epiq, 3.427 doanh nghiệp ở Mỹ đã nộp đơn xin bảo hộ phá sản vào nửa đầu năm 2020. CNN đưa tin, NPC International- đơn vị quản lý chuỗi 1.200 cửa hàng Pizza Hut và gần 400 nhà hàng Wendy tại Mỹ, đã nộp đơn xin phá sản với số nợ 1 tỉ USD. Chesapeake Energy Corporation là hãng dầu khí lớn nhất tại Mỹ đến nay phải nộp đơn xin phá sản vì đại, chấm dứt kỉ nguyên thịnh vượng của Chesapeake - công ti tiên phong trong việc bùng nổ khai thác đá phiến tại Mỹ, hãng khí đốt lớn thứ 6 trong nước. LATAM Airlines - hãng hàng không lớn nhất khu vực Mỹ Latinh ngày $26 / 5$ đã đệ đơn xin phá sản tại Mỹ sau khi hoạt động kinh doanh sụt giảm mạnh do đại dịch viêm đường hô hấp cấp Covid-19. Ngày 15/5/2020, JCPenney - chuỗi cửa hàng bán lẻ có tên tuổi tại Mỹ, trở thành tập đoàn bán lẻ tiếp theo rơi vào cảnh phá sản do tác động của đại dịch viêm đường hô hấp cấp Covid-19. Tại Trung Quốc: Hơn 460.000 công ty 
của Trung Quốc đã phá sản trong quý đầu tiên năm 2020, hơn một nửa trong số đó là doanh nghiệp trẻ hoạt động khoảng 3 năm. Tại Nhật Bản: Công ti dệt may lớn nhất - Renown đã tuyên bố phá sản vào ngày 15/5/2020 với khoản nợ 13.9 tỷ Yên Nhật. Từ tháng 2 đến tháng 6 năm 2020, đã có hơn 140 công ty tại Nhật Bản tuyên bố phá sản (Tú Quỳnh, 2020).

Theo số liệu cuối năm 2020 từ Tổng cục Thống kê, năm 2020 có tổng cộng 101,7 nghìn doanh nghiệp tạm ngừng kinh doanh có thời hạn, ngừng hoạt động chờ làm thủ tục giải thể và hoàn tất thủ tục giải thể, tăng $13,9 \%$ so với năm trước. Trong đó, gồm 46,6 nghìn doanh nghiệp tạm ngừng kinh doanh có thời hạn, tăng 62,2\%; gần 37,7 nghìn doanh nghiệp ngừng hoạt động chờ làm thủ tục giải thể, giảm 13,8\%; gần 17,5 nghìn doanh nghiệp hoàn tất thủ tục giải thể, tăng 3,7\%. Tính riêng thành phố Hồ Chí Minh, từ đầu năm 2020 đến tháng 11, đã có hơn 13.000 đơn vị tạm ngưng kinh doanh, gần 5.200 doanh nghiệp hoàn tất thủ tục giải thể...(Nguyên Nga, 2020)

Số liệu thống kê từ Cổng thông tin quốc gia về đăng kí doanh nghiệp, trong 9 tháng đầu năm 2020, số doanh nghiệp đăng kí mới sụt giảm nghiêm trọng, giảm $3.2 \%$ so với cùng kì. Giảm mạnh nhất là nhóm doanh nghiệp hoạt động trong lĩnh vực nghệ thuật, vui chơi và giải trí, kinh doanh bất động sản. Các doanh nghiệp hoạt động trong lĩnh vực dịch vụ khác có số lượng đăng kí mới giảm $32.1 \%$ so cùng kì năm 2019. Doanh thu du lịch lữ hành trong 8 tháng đầu năm 2020 giảm sâu 54.4\% so với cùng kì năm trước. VCCI phối hợp với WB đã thực hiện khảo sát và đưa ra báo cáo tác động của dịch COVID-19 đối với doanh nghiệp Việt Nam, nhấn mạnh đại dịch COVID-19 đã gây tác động nghiêm trọng tới hoạt động sản xuất kinh doanh của các doanh nghiệp. Cụ thể: 87,2\% doanh nghiệp chịu tác động tiêu cực bởi dịch bệnh, chỉ có $11 \%$ không ảnh hưởng gì, và gần $2 \%$ vẫn kinh doanh tốt. Lĩnh vực chịu ảnh hưởng lớn nhất là may mặc (97\% doanh nghiệp), thông tin, truyền thông $(96 \%$ doanh nghiệp), thiết bị điện ( $94 \%$ doanh nghiệp), sản xuất xe có động cơ ( $93 \%$ doanh nghiệp)...(UNWTO \& VCCI, 2020)

Tương tự, kết quả khảo sát 1.564 doanh nghiệp FDI tại Việt Nam cũng ghi nhận 87,9\% chịu tác động tiêu cực từ dịch bệnh, 11,4\% không ảnh hưởng gì, chỉ có 0,8\% vẫn kinh doanh tốt, $22 \%$ doanh nghiệp FDI cho biết phải sa thải lao động do tình hình kinh doanh suy giảm, số lao động buộc phải nghỉ việc xấp xỉ 30\% tổng số lao động làm việc tại doanh nghiệp(UNWTO \& VCCI, 2020). Kết quả khảo sát của Tổng cục Thống kê cũng cho thấy, tại thời điểm từ 10/4/2020-20/4/2020 bằng hình 
thức trực tuyến đối với 126.565 doanh nghiệp tham gia trả lời; tại thời điểm điều tra, có tới $85,7 \%$ số doanh nghiệp trên phạm vi cả nước bị tác động bởi dịch COVID$19 ; 57,7 \%$ cho rằng thị trường tiêu thụ bị giảm mạnh; Có $22,1 \%$ doanh nghiệp bị thiếu hụt nguyên liệu đầu vào và $45,5 \%$ số doanh nghiệp khảo sát đang bị thiếu hụt nguồn vốn cho sản xuất kinh doanh (BT, 2020).

Cho tới hiện tại, những số liệu được nêu trên vẫn đang không ngừng thay đổi trước diễn biến phức tạp khôn lường của đại dịch toàn cầu COVID-19. Các doanh nghiệp không thể lường trước được rằng mình sẽ còn phải đối mặt với bao nhiêu ảnh hưởng tiêu cực mà dịch bệnh đem lại và khi nào chính bản thân doanh nghiệp đó sẽ tuột tay khỏi bờ vực phá sản. Những lo lắng của các doanh nghiệp cũng ngầm chứa nỗi âu lo cho nền tảng kinh tế của một quốc gia đang trên đà phát triển như Việt Nam. Điều này khẳng định sự đổi mới tư duy phát triển của các chủ doanh nghiệp cũng như của Chính phủ Việt Nam hay sự can thiệp giúp đỡ các của Chính phủ là vô cùng cấp bách và cần thiết. Từ đó, khái niệm về trạng thái "bình thường mới" một lần nữa được đề cập đến sau cuộc khủng hoảng kinh tế như một giải pháp kịp thời hỗ trợ và cứu vớt doanh nghiệp vượt qua khủng hoảng thời kì đại dịch toàn cầu. Khi những chính sách cũ hỗ trợ doanh nghiệp không còn đảm bảo tính hiệu quả trong tình hình mới thì sự ra đời của những chính sách mới phù hợp với bối cảnh vừa cần phát triển kinh tế, vừa đảm bảo công tác phòng chống dịch hoàn toàn là lẽ tự nhiên tất yếu. Vậy nội dung của chính sách "bình thường mới” ra sao? Chính phủ đã hành động bằng cách nào? Việc áp dụng những chính sách "bình thường mới” đem lại những hiệu quả đáng kể nào? Và quan trọng nhất là cơ hội "hồi sinh" cho các doanh nghiệp khả thi đến đâu? Câu trả lời cho những câu hỏi này sẽ được trình bày cụ thể trong phần 2 của bài tiểu luận. 


\section{TÀI LIỆU THAM KHẢO}

BBT. (2021). TÁC ĐÔNNG CỦA DICH COVID-19 ĐẾN TĂNG TRỦỎNG CÁC KHU VỰC KINH TÉ QUÝ III NĂM 2021. Tổng Cục Thống Kê.

BT. (2020). Doanh nghiệp tìm "lối ra" trong bối cảnh dịch COVID-19 lan rộng trong cộng đồng. Báo Điện Tử Đảng Cộng Sản Việt Nam.

La, V. P. et al. (2020). Policy response, social media and science journalism for the sustainability of the public health system amid the COVID-19 outbreak: The vietnam lessons. Sustainability (Switzerland), 12(7). https://doi.org/10.3390/su12072931

Ngọc, M. (2021). Tháo gõ khó khăn, thúc đẩy phục hồi kinh tế trong bối cảnh đại dịch. Báo Điện Tử - Đảng Cộng Sản Việt Nam. https://dangcongsan.vn/phongchong-dich-covid-19/thao-go-kho-khan-thuc-day-phuc-hoi-kinh-te-trong-boicanh-dai-dich-590784.html

Nguyên Nga. (2020). Số doanh nghiệp phá sản tăng mạnh. Thanhnien.Vn.

Tú Quỳnh. (2020). Hàng loạt doanh nghiệp lớn phá sản vì đại dịch COVID - 19. Việt Báo.

UNWTO, \& VCCI. (2020). Tác động của dịch bệnh Covid-19 đối với doanh nghiệp Việt Nam - Một số phát hiện chính tì̀ điều tra doanh nghiệp năm 2020.

Vân Thanh. (2021). Công bố báo cáo "Tác động của dịch bệnh COVID-19 đối với doanh nghiệp Việt Nam”. Trang Tin Điện Tử ĐẢNG Bộ TP. HCM.

Vuong, Q.H., et al. (2022). Covid-19 vaccines production and societal immunization under the serendipity-mindsponge-3D knowledge management theory and conceptual framework. Humanities \& Social Sciences Communications, 9, 22. Retrieved from: https://www.nature.com/articles/s41599-022-01034-6 